I Universidad Central de Chile (UCEN), Santiago, Chile

felipe.gonzalez@ucentral.cl

https://orcid.org/oooo-0002-7666-I 28I

Felipe González-López'

\title{
SOCIETY AGAINST MARIKETS. THE COMMODIFICATION OF MONEY AND THE REPUDIATION OF DEBT
}

The financialization of the economy and society engenders different forms of resistance that fall under the category of debt repudiation, which we can conceive as a distinctive feature of advanced capitalism. From anti-debt movements in Mexico, Spain, Poland, Croatia and Chile to occupy movements in the United States, Israel and Canada, to mention a few examples, organizations have emerged to repudiate both debt and the centrality of financial markets.

The financialization literature has yet to come to terms with these conflicts since it has mostly stressed the disciplining character of finance, rather than its resistance and repudiation. For two decades now, financialization studies have invested considerable effort in mapping the dense network of actors, devices, institutions, and processes that lead to the financialization of the economy and society (Krippner, 2005; Langley, 2008; Mader, Mertens \& Van der Zwan, 2020; Van der Zwan, 20I4), including households (Montgomerie, 2013), companies (Fligstein \& Shin, 2007), food (Clapp, 20I4), pension funds (Macheda, 20I 2), education (Eaton et al., 20I6), poverty (Mader, 20I5) and culture (Langley, 20I0), to mention a few. However, conflicts around debt or the politicization of finance do not stand as a subject of inquiry in itself. Social studies of finance have tackled this gap indirectly and began to address the way households "domesticated" finance and shaped it in novel and unpredictable ways (Deville et al., 20I6), often stressing the conflictive relationship that emerges in this process (Montgomerie \& Tepe-Belfrage, 20 I9; Pellandini-Simányi, Hammer \& Vargha, 
20I5). Investigating the repudiation of debt represents an addition to this collective effort.

How should we investigate the repudiation of debt? There is no single framework to encompass the enormous variety of debt repudiation across different scales (local and international social movements) and domains (student debt, mortgages, sovereign debt, and so on). The documentation of debt repudiation cases, moreover, remains scattered across distinct disciplinary fields, ranging from international political economy to scholarship on social movements. Consequently, the existing works interrogate the empirical world pursuing different research goals and depicting both distinct aspects of the repudiation of debt and different understandings of what debt is. International political economists, for instance, investigate the default probabilities of a given government (Asonuma, 20I6; Tomz \& Wright, 2013), the political economy of debt cancellation (Ocampo et al., 20I4), or offer critical insights into the way in which debt serves the political project of neoliberalism (Soederberg, 2013). Scholars of social movements, on the other hand, offer a variegated approach to anti-debt movements. Guzmán (20I5), for example, studies why people trust institutional misinformation from lenders over alternative information provided by anti-debt movements. Brumley (20I3) studies the shifts in collective identities of the Mexican debtors' movement known as El Barzón. Many scholars tackle issues such as the resistance engendered by austerity policies (Della Porta, 20I5), or offer historical accounts of antidebt movements focusing on their characteristics and accomplishments (Marchini, 2004; Ross, 2014; Williams, I996). Finally, some scholars offer broader reflections on how to resist debt (Caffentzis, 2013; Caraus, 2016).

The goal of this article is twofold. Conceptually, it seeks to organize a wide range of cases of debt repudiation under an economic sociology framework that draws from Karl Polanyi's notion of "double movement" to help contextualize debt repudiation within a broader historical context. I argue that Polanyi's framework offers four main vantage points to address the repudiation of debt: it shows the systemic interdependence of the commodification of land, labor, and money (financialization) in the era of neoliberalism; it sheds light on how different forms of debt repudiation intertwine with broader movements against financial markets and austerity politics worldwide; it draws attention to the way the expansion of finance erodes democratic institutions; and, finally, Polanyi's work draws attention to the moral dimension of economic institutions - not least debt, which lies at the base of the micro and macro-mobilization processes through which actors seek to subvert financial obligations.

The second goal of the article is empirical. It seeks to map both financialization processes and related forms of debt repudiation, whose documentation remains dispersed across various disciplinary fields. For this I rely on three main sources: first, I draw from the extant financialization literature to characterize both the commodification of money as a transformation of economic 
and social institutions, and how it leads to the advancement of financial power over different realms of society, most notably companies, households, and governments. Second, I rely on dispersed accounts of anti-debt movements, as documented by scholars of social movements, international political economy analysts, activists and, to a lesser extent, financialization scholars. Finally, I draw many insights from my own ethnographic research on social movements of student debtors in Chile, which I conducted between 2016 and 2018. In this fieldwork, I spent two years following activists from the movement Deuda Educativa in Santiago, conducting direct observation - and later participant observation - in assemblies, public debates, and protests. I held 36 recorded interviews with activists, debtors, experts, and policymakers, as well as countless conversations and fieldnotes.

The article has three parts. The first section outlines the conceptual framework that draws from Polanyi's notion of double movement to frame financialization and debt repudiation as two related processes. Then, I sketch the way in which the commodification of money - namely, financialization entails a transformation of the economic and social institutions that sustain debt relations in society. In the final section, I explore the rise of social movements of debtors at the national level, and the repudiation of external debt. In doing so, I try to shed light on the social, cultural, and political processes underpinning the politicization of debt, as well as the multiple connections among different types of mobilizations against financial power.

\section{POLANYI'S DOUBLE MOVEMENT AND FINANCIALIZATION}

According to Polanyi (I945), the attempt to impose laissez-faire ideology in the nineteenth century came at the cost of an entire re-organization of society driven by the marketization of three "fictitious commodities" that were created neither by nor for markets: labor, land, and money. The commodification of these "fictitious commodities," wrote Polanyi, engendered a reaction of society, a countermovement that aimed to protect itself from disruptive market forces and established regulatory bodies. These protective forces of society against markets took different forms, many of which were spontaneous responses that came from the most affected groups of society, the landed gentry and the working classes, which explains why these reactions came in the form of both conservative and progressive movements. Thus, for example, while the protection of land from commodification included agricultural tariffs to ameliorate the effects of competition, labor protection was driven by the demands of the rising working classes for government assistance to the unemployed, as well as regulations such as limiting the length of the working day (Polanyi, I945). In this way, Polanyi asserted that the implementation of free market policies was followed by successive regulatory interventions that aimed to establish protective laws and restrictions on markets. 
The commodification of the fictitious commodity of "money," on the other hand, was engendered by haute finance during the nineteenth century, which sought in the gold standard the means to achieve a stable store of value (Block \& Somers, 20I4). However, it brought about deflation, inaugurating a new era of endemic conflicts. The reactions of society were multiple and had no pre-established direction. Depending on the dominant class coalitions on each country, the gold standard gave birth to totalitarian movements, democratic arrangements, or revolutionary reactions.

At its base, Polanyi's "countermovement" asserts not only the attempt to protect society against market logics, but also the primacy of social and cultural institutions over the economic principle of profitmaking, which explains why "persons belonging to various economic strata unconsciously joined forces to meet the danger" (Block \& Somers, 2014: 63). Through these protective forces, the economy is "embedded" back into the cultural institutions of society and not the other way around.

Although Polanyi used the concept to make sense of the collapse of the liberal period of the nineteenth century, scholars have re-interpreted it as a means to critically assess the free market ideology of the neoliberal age, as well as make sense of the way in which subordinate forces seek to restrain the advance of self-regulating markets (Block \& Somers, 2014; Dale, 2010; Levien, 2007; Silver \& Arrighi, 2003; Worth, 2013). Following Polanyi, it is possible to assert the role of both progressive and conservative responses to a new wave of marketization in the era of globalization and neoliberalism, which range from social movements and organizations demanding environmental regulations, to religious congregations providing charity, or right-wing populist governments eroding free trade.

I see in the Polanyian "double movement" a vantage point to characterize the advance of financialization as a second wave in the commodification of the fictitious commodity of "money," though different in nature from the early marketization of the nineteenth century. In this new wave, neoliberalism reshaped the economic and social institutions that had curbed the advance of finance, most notably through the deregulation of financial markets and the dismantling of both the welfare and tax states. While the former process paved the way for the implementation of multiple innovations that revolutionized financial markets, the latter created the conditions to force both households and governments to increasingly rely on financial markets to cope with market volatilities and distributive conflicts (Streeck, 20I4).

Following Polanyi's idea of double movement, it becomes clear that the financialization literature has been primarily concerned with one part of the historical process, the movement, understanding the way finance expands the frontiers of markets and its devastating effects over society. It also tells us that scholars have been less concerned with the "counter-movement," or the way finance's 
expansion confronts resistances and a variated reaction from society to protect itself from financialization and its economic and moral imperatives.

I conceive financialization and the repudiation of debt as two sides of the same process, the "movement" and the "counter-movement" engendered by the "commodification of money" that took place in the second half of the twentieth century. To illustrate this idea, I begin by characterizing the "movement" as the expansion of financial markets and its imperatives into different realms of society. Second, I characterize the "counter-movement" of society against (financial) markets as the micro- and macro-mobilization processes of resisting and dismantling financialization, characterized by the attempt to subsume the dominant principles of economic profit and the morality of debt into a new hierarchy of moral principles underlying financial obligations.

\section{FINANCIALIZATION AND THE FICTITIOUS COMMODITY OF MONEY UNDER NEOLIBERALISM}

The current cycle of the commodification of money, known to us as "financialization," can be characterized as a displacement of power from financial institutions to financial markets, reinforcing the "tendency for profit making in the economy to occur increasingly through financial channels rather than productive activities" (Krippner, 20I I: 4). This process took shape roughly around the I980s in the developed world, where financial markets reached a stage of impressive innovation, complexity and dynamism led by liberalization and deregulation. Nowadays, astonishing levels of credit, debts, stocks and insurances are traded on a real-time basis with the help of information technologies and risk-management techniques, becoming a global phenomenon (Rona-Tas \& Guseva, 2018). This phenomenon was to a great extent driven by the fact that non-financial firms turn to finance as a source of profits. Business came to be increasingly funded by financial markets, rather than banks, which resulted in a situation in which the growth and complexity of intermediary activities shaped the behavior of both firms and households (Erturk et al., 2007).

Neoliberalism was the context in which money became commodified, producing a systemic interdependence between the further commodification of labor and land through successive institutional changes, with privatizations - of both public goods and nature - standing out as a main force. This systemic interdependence is nowhere more visible than in the financialization of households. It began with the retrenchment of the welfare state and the privatization of public services (Montgomerie, 2006), which lead to an ever increasing dependence of households on different sources of credit to continue to reproduce their everyday life, acquire housing, consume, access higher education, possess a safety net against the flexibility of labor markets, and access privatized health services (Montgomerie, 2013; Streeck, 20I4). The extension of credit to households was primarily facilitated by a revolution in retail banking practices during the I 980 , 
which turned workers' salaries into a source of profit and designed complex innovations, such as asset-backed securities and credit default swaps, that allowed financial markets to extract value from labor (Langley, 20Io; Lapavitsas, 20I I). Pensions and savings were invested in mutual funds, whereas credit cards and auto loans, together with mortgages, were turned into bonds traded in international financial markets (Davis \& Kim, 20I5). In this way, the fate of the salaried (labor) and their property (land) became tied to the fate of financial markets, something that many came to realize in the financial crash of 2008.

As with the early commodification of fictitious commodities that Polanyi described in the nineteenth century - and despite the renewed free market ideology - the commodification of money has been largely driven by state action, which actively sought to create all sorts of financial markets alongside the privatization of public goods, among which markets for housing (Quinn, 20I0) and higher education (González-López, 2020b) became prominent policy fields. The same holds true for markets in consumer goods, which in some cases have been promoted by governments as a social right (Calder, I999; González-López, 2018; Trumbull, 20I4), as well as for the market in micro-credit to the poor, widely conceived as a policy panacea to fight poverty by governments and international agencies alike (González-López, 2020a; Mader, 2015).

In this context, mounting levels of debt have sparked several crises worldwide, triggering fragmented - although related - responses from society. On one hand, the housing bubble exploded in 2008 in the form of a global crisis that erased hundreds of thousands of jobs and triggered home evictions, paving the way for the rise of housing movements (Casellas \& Sala, 2017). Student loan debt, on the other hand, skyrocketed in many countries as a response to the privatization of higher education, and workers increasingly face saturated labor markets whose salaries barely help them meet their financial commitments (González-López, 2020b; Larson, 20I4). Moreover, the financial crash of 2008 and later the sovereign debt crisis - exposed the way in which money commodification contributed to the erosion of democratic institutions. Because banks and financial institutions now concentrate so much power, they have been able to demand massive bailouts, while at the same time avoiding being held accountable for the damage they have inflicted on citizens and public finance.

The rise of international financial powers connects directly with the proliferation of manifestations worldwide, from occupy movements in Spain and the US to spontaneous protests in Israel, Canada, Greece and so on (Calhoun, 20I3). Such protests called into question the capacity of financial powers to transfer the costs of the crises they themselves brought into being onto national governments and ordinary citizens in the form of bailout packages, austerity policies, home evictions, and mounting levels of household and public debt (Berglund, 20I8). Thus, these movements have denounced the way governments handle finance, challenged the attempts to implement austerity policies that 
favor international financial markets and fought to reclaim democratic control over national institutions. In parallel, anti-debt movements have repudiated financial obligations outright and demanded government intervention to relieve debtors and erase debt.

\section{THE FINANCIALIZATION OF CULTURAL INSTITUTIONS}

As finance pervades the everyday life of ordinary citizens, the commodification of money also subsumes cultural institutions under the logic of finance. Mortgages, consumer loans, credit cards, student loans, insurance, and pension funds, to mention a few, became central to household budgeting, which increasingly embrace an orientation towards accounting and risk across several domains (Martin, 2008). This is reinforced by the proliferation of credit ratings and financial discourses that stress entrepreneurial spirit and values, inviting people to adopt an entrepreneurial management of the household and to transform it into an object of speculation (Fligstein \& Goldstein, 2015).

This process, known as the financialization of everyday life (van der Zwan, 20I4), bears a striking resemblance to Polanyi's description of how the implementation of laissez-faire capitalism entailed the subsuming of "the social" to the imperatives of the market economy. In this sense, we can conceive financialization as a form of "colonization" through which motives, values, calculative frames, and subjectivities spread from financial markets to every domain of life, producing new subjectivities and specific ways of exerting power over individual conduct (Langley, 2010). Banking practices, for instance, address subjects as responsible and calculative agents who are meant to take control over their own economic fates and assume responsibility for their own welfare (Geisst, 2009; Manning, 200I; Pellandini-Simányi, Hammer \& Vargha, 20I5). In a similar vein, as credit ratings become a true social test for the credibility of individuals, they prompt people to change their behavior in order to improve their scoring (Langley, 2008).

The commodification of money thus entailed a re-configuration of social ties through the proliferation of debt relations, which can be conceived as power relations maintained and reinforced through both external and internal means of coercion (Davey, 20I9; González-López, 20I8). External coercion is set by institutional means. So long as financial contracts work under the assumption that actors will pay back their debts, there exists a social infrastructure in charge of monitoring and enforcing debt compliance, which includes credit bureaus, bankruptcy laws, and consumer protection agencies. The extent to which these institutional arrangements favor the expansion of finance or protect consumers against powerful lenders varies from country to country (Ramsay, 20I2).

The internal coercion of debt, on the other hand, relies on moral frames and public discourses that assert individual responsibility (Jefferson, 2013). Debt is itself a moral institution, underpinned by the obligation to pay back, which is why it is always framed in moral ways, as something that ought to be, forming the base of social hierarchies (Peebles, 20I0). Financial markets work in large part because people internalize the moral obligation to pay back their debts, which is systematically reproduced through media discourses, marketing practices, and conventional wisdom (Graeber, 20I I). This idea is reinforced by shared values such as meritocracy and individual responsibility, which are systematically promoted by media outlets, financial institutions, and public agencies. 
These institutional and moral aspects assert both the material and symbolic power of debt, respectively, and make debt repudiation an unlikely event. In the third part of this article, I turn to a very disperse body of literature to outline what it means to repudiate debt from a sociological point of view, mapping different forms of debt repudiation as a social response to the commodification of money under neoliberalism.

\section{THE POLANYIAN COUNTERMOVEMENT OF SOCIETY AND THE REPUDIATION OF DEBT}

There are several ways in which society protects itself from the advancement of finance and the commodification of money. In this article, I am concerned with a particular form of resistance: debt repudiation.

What is debt "repudiation" and how does it differ from simple "default"? The simplest distinction is that default is the fact of not complying with financial obligations, whereas repudiation entails a purposeful rejection of such an obligation on moral grounds. On many occasions, debtors may simply be unable to pay back their debts. Income shocks may leave a household without the resources to pay back its mortgage or credit card bill outright. In other cases, the burden of a debt may become more unbearable than the moral imperative to pay it back, and individuals may see more benefits in defaulting than in paying. What makes debt repudiation different from merely defaulting, however, is the grounds on which this action takes place. Debt default may arise from the impossibility of paying or as a strategic response to a situation, whereas "repudiation" is a conscious way of denying the obligation to pay one's debt on moral or political grounds. It is the moral foundation of debt repudiation that allows us to talk of a Polanyian countermovement, as it implies reembedding economic obligations and logics into broader frames of justice and legitimacy.

When do actors reject debt on moral grounds? Feelings of anger, injustice and more broadly grievance are at the basis of many actions of disobedience and the disruption of social order (Diani, I 992; Jasper, 2004; Polleta \& Jasper, 200I). This is no different in the case of debt repudiation. Debt repudiation originates with the erosion of the legitimacy of debt, normally stemming from what is perceived as an unfair situation, either due to the debt's illegitimate origin or because it does not fulfil the purpose for which it was originally intended. In a sudden devaluation of housing - as occurred during the $2008 \mathrm{crisis}$, for example - a mortgage debt may become not only unbearable but also illegitimate. What is at stake in a case like this is that the promise to pay back one's debt is made under the assumption of another underlying (and unfulfilled) promise, namely that the value of the house will increase with time (or at least not fall). Such is also the case with student loans. Student loans are issued under the assumption that the individual debtor will capitalize their education over time, receiving a higher salary at a later point in time when the debt needs to be paid back (Ziderman, 20I3). Nevertheless, this may become an unfulfilled promise for many. The lack of opportunities for young people, the saturation of labor markets, and the frustration this produces are all major drivers of the repudiation of student loans and the emergence of social movements focused on debt (Larson, 20I4). Moreover, as people conceive education to be a social right, student loans are perceived as illegitimate in their origins. 
Seen in this way, the repudiation of debt may be either individual or collective. In the remainder of this article, I am concerned with collective ways of repudiating debt that require the enrolment of various debtors and the politicization of debt more broadly. I focus on the collective repudiation of debt because it represents a broader "politicization of debt," or countermovement of debtors, which I understand as the coordination of collective action to repudiate debt publicly and to demand the intervention of third parties to enforce underlying obligations and mitigate power asymmetries. It is this type of repudiation which leads to the demand for public interventions to create regulatory bodies in a Polanyian sense.

\section{Anti-debt movements}

The rise of social movements of debtors is one distinctive way in which society protects itself from financial markets. As I show in this section, these stand out as a countermovement to the further commodification of money insofar as they seek to re-shape financial obligations on moral grounds (re-embed the economy), create collective power to balance asymmetries, and target authorities to shape or create regulatory bodies.

Anti-debt movements are the result of a complex process that involves both the agency of activists and the effects of broader social forces, and they may unfold either through slow processes of collective identity formation or as a more immediate response to dramatic events.

Many social movements of debtors arise from dramatic events that make their debt illegitimate, an impossible burden, or both simultaneously, thus pushing people into coordinated action. Such is the case, for example, of the Mexican El Barzón movement. After the liberalization of the Mexican economy in the I990s, currency exchange and interest rates became free-floating. In 1994, the sudden devaluation of the Mexican peso against the US dollar turned mortgage debts into an impossible burden for many Mexicans, who, in response, organized to defend their properties (Kingsolver, 2008). El Barzón grew out of the organization of farmers spread throughout the country (most notably Jalisco and Zacatecas), and gathered a wide range of people from the middle classes to land-holding farmers, which led it to become a broader political movement (Brumley, 2013).

A similar story can be told about housing mortgage debtors in Spain. Perhaps one of the most documented cases is the Plataforma de Afectados por la Hipoteca (PAH), which began in the city of Barcelona as a reaction to home evictions after the financial crisis of 2008 and the implosion of the Spanish real estate boom. Massive foreclosures sparked after the rise in unemployment rates in the $20 \mathrm{Ios}$, which reached $25 \%$ of total population and more than $50 \%$ of people under the age of 25 (Casellas \& Sala, 20I7). In this context, citizens organized to resist evictions and demand a fairer mortgage law, which has so far worked in favor of debt repayment and left homeowners to their own fate. The PAH stood as a grassroots organization whose aim was to protect the right of citizens affected by evictions, proposing as a solution the repossession of houses and the transformation of empty properties into social housing. Later, during the rise of the I5 May movement in 
$20 \mathrm{I}$, it became a hosting organization for many activists seeking to fight austerity policies and home evictions alike. Currently, the PAH network is the most important organization dealing with home evictions and with transforming the Spanish mortgage law (Ordóñez, Feenstra, \& Torney, 2015).

\section{Creating a collective identity for debtors}

Dramatic events tend to trigger debt repudiation as an immediate response, yet this is not always the case. Even a huge foreclosure crisis, such as the one that followed the financial meltdown of 2007, may not be enough to trigger the mobilization of debtors. As Robinson (2013) shows, for example, no movement followed the high rates of foreclosure among workers of southern California, even though it was among the most affected areas. In this case, a mix of interrelated phenomena prevented workers from mobilizing, such as a community individualistic ideology that suppresses discontent among people suffering foreclosures, the general lack of engagement in civic organizations, and participation in religious organizations that were indifferent or even opposed to any action.

Social movements usually arise when shared feelings of fear and injustice motivate action (Benford, I997; Castells, 2012). In the case of debt, there are several obstacles that prevent this from happening. On one hand, debt is marketized and experienced as the outcome of individual decisions. If debtors concur freely to take on debt, why would they organize to collectively repudiate it? Moreover, credit is issued under the promise of future repayment, which is endorsed by a sense of moral obligation. So how do debtors change their moral frames, and how do they overcome feelings of shame or guilt to collectively demand debt relief? Seen from this angle, anti-debt movements arise from a complex problem: to change the moral frames of other debtors in order to enlist them and, later, create collective material and symbolic power to both counterbalance the power of financial actors and convince broader publics and political authorities about the necessity of debt relief.

To illustrate these processes, I draw from (though not exclusively) my own research on the rise of social movements of student debtors, conducted in Chile between 2016 and 2017. Chile has one of the most expensive higher education systems in the world (in terms of PPP, purchasing power parity) (Garritzmann, 20I6), and different student loan schemes have been systematically used since the I980s to meet the demand for higher education in a context of low wages. The conflict around student debt began during the early 2010 s in the wake of the student movement, which demanded free and public education. By then, the first generation of students indebted to the State Guaranteed Loan (created in 2005) were having to pay back their student loans. Default rates soared to $60 \%$, one third of debtors had to use almost $20 \%$ of their monthly income to service their debt, and $60 \%$ of defaulters did not even finish up in their chosen careers (González-López, 2018). 
In this context, debtors from different loan schemes organized in 2013 to demand debt relief and lower interest rates, among other changes to the educational system. Some of these concerns were tackled during the student mobilizations in 2012, but the demand for debt relief gained momentum at a later point with the transition towards a new higher education system. During the 2017 presidential election, the left-wing candidate Beatriz Sánchez worked hand-in-hand with the movement and proposed a complete remission of student debt, although she did not manage to win the election. The examples I draw from here come from ethnographic research I conducted between 2016 and 2017 in Santiago de Chile with the movement Deuda Educativa. It includes 36 recorded interviews with activists, debtors, policymakers, and authorities, as well as countless fieldnotes taken during assemblies, protests, and the everyday coordination of activists through different virtual platforms, most notably WhatsApp.

What stands out in this case is that the first move to politicize (student) debt is to turn it into a collective - rather than individual - phenomenon. Antidebt movements bring together people who would otherwise not have met or come together in a political movement. They share grievances, feelings of injustice, and anger stemming from the unfair terms of debt contracts, as well as a lack of protection against powerful lenders. However, they are not necessarily aware of these mutual connections. Activists or lone resistors searching for others are needed in any attempt to "collectivize debts" (id est to unite people currently bearing the burden of debt in isolation in an acknowledgement that they share the same grievances). This is how Deuda Educativa was born, out of the desperate attempts of lone resistors to find others experiencing the same problem and sharing the same feelings of outrage.

Activists connecting debtors with the help of social media made the collectivization of debt possible in Chile, eliciting the feeling of "togetherness," a fundamental psychological mechanism that helps people overcome fear and engage in social movements (Castells, 20I2). But this alone is not enough. In the absence of dramatic events that directly prompt debtors to act (such as home evictions), scholars of social movement teach us that a necessary step to the rise of social movements of debtors is the creation of "collective action frames." These are the "interpretive packages that activists develop to mobilize potential adherents and constituents" (Polleta \& Jasper, 200I: 29I), which stand as a precondition for any social movement to arise. It is through these collective action frames that activists seek to target their "sentiment pools" and enlist adherents and supporters, as well as change normative and cultural representations of debt.

Initially, activists needed to create collective action frames to convince other debtors that they were not responsible for getting into debt in the first place, for failing in their payments, or for not being able to catch up with oth- 
ers. Collective action frames in this setting help shift blame attribution (Benford \& Snow, 2000) from the individual and isolated debtor to those that designed, implemented, and legitimized student loans as a solution to the rising cost of tuition fees: politicians. In other words, collective action frames were crucial to undermining existing conceptions of debt, overcoming the feelings of shame associated with it, and challenging the idea that debtors are individually responsible for their debt.

Bringing people together in parks, assemblies and public debates is a way of both collectivizing student (and other) debt and changing moral frames. People were able to acknowledge that their afflictions were shared by others, and that there were alternative ways of interpreting their own situation. In Chile, one of the most successful ways of doing this was by setting up a Facebook fan page, which today has around 200,000 followers. Such an outlet gave activists real leverage against politicians who have no wish to become the target of their videos, posts, or memes. Social media is a useful resource for this action in at least two ways. First, it provides a virtual space for isolated and dispersed debtors to meet. Second, it becomes a place where activists can foster group solidarity through memes and humorous posts, as well as any content that helps draw boundaries between "them" (the politicians responsible for their debt) and "us" (the victims of badly designed social policies). Group solidarity and collective identity were thus crafted in online platforms as much as in other public forums.

\section{The politicization of debt and the public sphere}

A third aspect of the rise of anti-debt movements is the need to address third parties enforcing debt relations, which means that the problem must be made public. This works by challenging moral conceptions about debt in the public sphere.

The case of student debt is again illustrative. The entire world is against debtors. From the point of view of policymakers, debt repudiation seems unnecessary and even unfair, as state subsidies attenuate market forces in considerable ways (Albrecht \& Ziderman, I993). After all, why should anyone revolt if student loans provide interest rates below market prices, flexible payment schemes, and in some cases include debt-relief mechanisms? Common sense is also on the side of governments and creditors. As long as governments issue student loans under the premise that students invest in themselves (human capital) and hence that benefits are private, paying back one's debt becomes both an economic and a moral imperative. Intellectuals, scholars, journalists, and the like play a crucial role in bringing these collective action frames to broader audiences to convince both public opinion and policymakers. This logic holds true for housing debtors as well. As Jefferson (2013) showed when investigating the reaction of Michigan's debtors after the foreclosure crisis that 
started in 2007, activists and homeowners produced public narratives of suicide or strategic default in order to contradict mainstream narratives that hold debtors responsible for the consequences of their housing debt.

Finally, politicizing debt not only entails the collectivization of debt, but also requires that this collectivity works in a coordinated way. In other words, debtors must unite and create collective power in a way that challenges the power asymmetries between creditors and governments on one side and isolated debtors on the other.

Creating collective power among people with student debt is exceedingly difficult as this takes organizational effort and time. Normally, debtors are no longer students when they become aware of the problem: they have families, jobs, and, of course, a debt to service. They do not belong to the same trade union, nor do they live in the same neighborhood - a key asset in the resistance to home evictions. They therefore need to create their own organizations. In Chile, assemblies with debtors consistently failed, as it was always difficult to bring together people who were both dispersed and busy. Building alliances with actual students was crucial to raise the issue and to occupy public spaces, but it was not enough to bring attention to the problem among authorities (GonzálezLópez, 202ob). In this scenario, activists in Chile found a more effective way of "organizing debtors": the judicialization of the struggle. They did this by launching six class actions against banks involved in the SGL (State Guaranteed Loan), which are still in courts. They claim that the contracts that originate student loans violate the country's consumer protection regulations.

More broadly, as financial obligations are embedded in different legal corpuses, the judicialization of conflicts is a common avenue for debtors to resist debt, and stands as a way of creating or shaping regulatory bodies to protect people from financial markets. Court action has been a common strategy among housing debtors. These have sought to judicialize the conflict in countries such as Croatia, Poland, and Spain, and they have been successful in changing different laws and regulations that institutionalize asymmetric power relations with creditors.

\section{Debt repudiation at the international level}

One distinct kind of conflict arising from the commodification of money originates in the relationship between financial powers - markets and states - and peripheral countries. Across several ages and regions, ruling countries - or empires - have exerted their domination and accumulated wealth with the help of debt. The rise of capitalism was no different, with major capital powers relying on external debt to assert their domination over rising republics (Toussaint, 20I9). Ever since the establishment of financial markets, credit contracts have been carefully designed to extract wealth from poorer countries and punish default, providing justifications for invasions, the occupation of territories, the 
establishment of favorable trading conditions, or the right to access natural resources in indebted countries. In this final section, I outline major features of the conflicts arising from the international debt system.

The history of debt repudiation among states is as long as capitalism itself. In Latin America, for example, the creation of new republics after the independence wars went hand-in-hand with the massive indebtedness of the recently established governments. Since this era, Latin American countries have experienced at least four debt crises which, as Toussaint (2019: I77) shows, are systematically preceded "by a boom in the central economies when a part of the surplus capital was recycled into the peripheral economies."

External debt exposes power imbalances between creditors and debtors, which many scholars and activists have sought to tackle through the writing of manifestos and campaigns in favor of debt repudiation. Two key elements help elucidate the repudiation of external debt: its origins and its consequences.

Governors can incur debt to repress citizens, pursue personal goals, or wage war against other states, and capitalism favors debt servitude in all events. It makes no distinction between dictatorships and democracies, which depend on financial markets and international credit alike. In this context, several scholars and international organizations have raised the case for debt repudiation at international level under the doctrine of the "odious debt" (Jayachandran \& Kremer, 2003). First, in I927, the Russian lawyer Alexander Sack, in his book Les effets des transformations des États sur leurs dettes publiques et autres obligations financières, established that debts contracted by dictators, absolute monarchies, or non-representative governments are illegitimate since they are not issued under consent, are not used for the benefit of the people, and originate from the dishonest machinations of the creditors (Ambrose, 2005).

In any case, the doctrine of "odious debt" is not majoritarian among legal scholars, and such a claim is also not enough to erase the debt held by countries, most of them poor. There need to be institutions and international organizations - or global powers - representing debtors. In recent times, the repudiation of external debt reached its peak in the wake of the external debt crisis in the I980s and I990s (Jones, 2013; Kugler, I987), where debt was conceived as a political tool through which global super powers - not least American banks - exerted their dominance over developing and poor countries (Fridell, 20I3a, 20I3b, 20I3c). As scholars and activists increasingly highlighted the negative effects of external debt on the economic and social performance of indebted countries (Hanlon, 2000), the doctrine of odious debt was used alongside other arguments to campaign for debt relief in the wake of the external debt crises of the ig8os and ig9os.

This points to a second feature relevant to understanding the repudiation of external debt: the effects of this debt. An external debt crisis is simple to understand. Loans that countries from the Global North issue to poor coun- 
tries from the Global South originate in development assistance, but end up producing a contrary effect. As interest rates soared during the I980s, debt payment became a nightmare for impoverished countries, which spent more on servicing debt than on public services, reversing the logic of development assistance between countries. In the end, these countries end up in an endless circle of taking more loans to service their debts (Ambrose, 2005).

According to the study by Pettifor and Greenhill (2003), developing countries in the I970s owed USD 72.7 bn to the rest of the world, corresponding to around I0\% of their collective GDP. However, by 2000 external debt rose to USD $2,527.3 \mathrm{bn}$, which amounted to $37 \%$ of GDP. As a share of GDP, Sub-Saharan countries accounted for the most heavily indebted countries, rising to $75 \%$ of GDP in 2000. In absolute terms, though, Latin America stood as the biggest debtor, its total debt having risen to USD 809 bn, or just under $40 \%$ of GDP. The external debt crisis of the I980 in Latin America provided a precedent for the way in which international organizations would handle external debt over the coming decades. The loan package that the IFM put together to bailout Mexico became a template for the negotiations that would ensue in the Ig9os in countries such as Indonesia, South Korea, Russia, and Brazil (Williams, 200I). It attached conditions that would re-orient the trajectories of developing countries from the import substitution to trade openness and cuts in social spending.

During the I990s, external debt was tackled by an unprecedented global campaign that advocated cancellation of the external debt of poor countries, an initiative known as the Jubilee 2000 movement (Ambrose, 2005; Fridell, 2013C; Reyes Tagle \& Sehm Patomäk, 2007; Somers, 20I7). This campaign originated from the writings of British scholar Martin Dent in the I990, which sought to link the turn of the new millennium with the ancient Biblical mandate of Jubilee. Working with the Debt Crisis Network, originally launched to demand debt relief for Third World countries, it assembled a platform that included Third World leaders to lobby the IMF and the World Bank. It enlisted political and religious leaders from Africa, the Americas, and Europe, who met the chief executive of the IMF in I996 to discuss Third World debt and make a decisive step towards the Heavily Indebted Poor Countries initiative (HIPC). The campaign launched an aggressive agenda that included meetings in different regions of the world, recruiting Catholic and Evangelical churches alongside local movements to support the initiative (Busby, 2007). The most eloquent move of the Jubilee 2000 movement was to systematically gather I0,000 people at the WTO and G8 summits in I997, I998, I999 and 2000 to demand debt relief on at least four grounds: unpayable debt that requires the sacrifice of poor people; debts that had been already paid in real terms; debt accrued to poorly designed programs; and odious debt inherited from predecessors. Similar manifestations were held in debtor countries, which successfully connected trade unions, grassroots organizations, churches, local activists opposing the IMF, and international activists. 
Jubilee 2000 was distinctive because it stood as a "global civil society" campaign. From the viewpoint of civil society, the collective action frame mobilized against external debt was switching the approach to overseas aid from "charity" to "global justice." The demand for debt cancelation was thus framed around concepts like "human rights" and the "historical debt" of the North to the Global South. In the end, the campaign did not manage to erase debt as intended, but it pushed the IMF to implement debt-relief programs, the most famous being the Heavily Indebted Poor Countries debt initiative (HIPC). To date, these initiatives have relieved more than USD Ioo billion in debt from 37 countries, $80 \%$ of which are concentrated in Africa. As critics have pointed out, however, debt relief programs run by international agencies work as a tool for concealing underlying power relations between countries, while simultaneously neutralizing the political underpinnings of debt relations (Fridell, 2013c).

\section{CONCLUSIÓN}

In this article, I have drawn on Karl Polanyi's work to frame both the financialization of society and different forms of debt repudiation as a "double movement" characterized by a second wave of money commodification and the attempts by society to protect itself from the advancement of finance. Polanyi's notion of double movement helps us place the repudiation of debt in a historical context, shedding light on the way in which the second wave of money commodification produces a systemic interdependence with the commodification of both labor and land. It also draws attention to how the expansion of finance entails a re-shaping of cultural institutions, which in turn engenders a reaction from society to protect itself from debt relations asserted through both internal and external means of coercion.

Mapping a wide range of anti-debt movements at national and international level, I have explored the conditions and processes that lead to a conscious repudiation of debt in a collective fashion. The way actors seek to repudiate debt differs across types of debt (housing, student loans, external debt) and context but, as a common ground, it entails the re-embedding of financial relations in new moral hierarchies, which establish who shall pay to whom and at what cost. This challenge broadly shared the same conceptions about the legitimacy of debt. As the analysis shows, changing these conceptions at the individual and social levels is a precondition for the politicization of debt in the public sphere.

Several questions still remain open for investigation, such as why social movements of debtors arise in some countries or areas and not in others; what repertories characterize debtors' actions across the globe; how they turn into broader political movements, such as El Barzón or the Plataforma de Afectados por la Hipoteca; what kind of narratives work best for politicizing debt in the public sphere; what tactics they deploy to counterbalance powerful creditors; and when they succeed and when they do not. This article provides 
a first step in this direction by offering a broad picture of the advancement of finance and the way it encounters different forms of resistance in society.

Received on 25/May/2020 | Revised on 09/Feb/202I | Approved on 09/Feb/202I

Felipe González-López is associate professor at the Universidad Central de Chile, where he leads since 2020 the Max Planck Partner Group for the Study of the Economy and the Public. He got his PhD in Sociology from the Max Plank Institute for the Study of Societies, in Cologne, where he researched the financialization of households. During his postdoctoral research in Chile, he researched the conditions that lead to the rise of social movements of debtors. His latest publications include "The financialization of social policy and the politicization of student debt in Chile" and "Micro-credit and The Financialization of Low-income Households", "Big data, algoritmos y política: las ciencias sociales en la era de las redes digitales" y "Crédito, deuda y gubernamentalidad financiera en Chile." 


\section{BIBLIOGRAPHY}

Albrecht, Douglas \& Ziderman, Adrian. (I993). Student Loans: an effective instrument for cost recovery in higher education? The World Bank Research Observer, 8/I, p. 7I-90. Retrieved from http://www.jstor.org/stable/3986488.

Ambrose, Soren. (2005). Social movements and the politics of debt cancellation. Chicago Journal of International Law, 6/I.

Asonuma, Tamon. (20I6). Serial sovereign defaults and debt restructurings. Retrieved from https://www.imf.org. Benford, Robert D. (1997). An insider's critique of the social movement Framing Perspective*. Sociological Inquiry, 67/4, p. 409-430. doi:Io.IIII/j.I475-682X.I997.tboo445.x.

Benford, Robert D. \& Snow, David A. (2000). Framing processes and social movements: an overview and assessment. Annual Review of Sociology, 26, p. 6II-639. Retrieved from http://www.jstor.org/stable/223459.

Berglund, Oscar. (2018). Contesting actually existing austerity. New Political Economy, 23/6, p. 804-8I8. doi:I0.1080 /I3563467.2017.1401056.

Block, Fred \& Somers, Margaret R. (20I4). The power of market fundamentalism. Karl Polanyi's Critique. London: Harvard University Press.

Brumley, Krista M. (2013). From responsible debtors to citizens: collective identity in the debtors' movement in Monterrey, Mexico. Journal of Contemporary Ethnography, 42/2, p. I35-I68.

Busby, Joshua W. (2007). Bono made Jesse Helms cry: jubilee 2000 , debt relief, and moral action in international politics. International Studies Quarterly, 51/2, p. 247-275. doi:IO.II I I/j.I468-2478.2007.0045I.X.

Caffentzis, George. (2013). Reflections on the history of debt resistance: the case of El Barzón. South Atlantic Quarterly, II2/4, p. 824-830. doi:IO.I2I5/00382876-23453I5.

Calder, Lendol. (1999). Financing the American dream: a cultural history of consumer credit. Princeton: Princeton University Press.

Calhoun, Craig. (2013). Occupy Wall Street in perspective. The British Journal of Sociology, 64/I, p. 26-38. doi:IO.I I I I/I 468-4446.I 2002. 
Caraus, Tamara. (2016). Debt resistance: beyond or within capitalism. Filozofija i Drustvo, 27/I.

Casellas, Antonia \& Sala, Eduard. (2017). Home eviction, grassroots organisations and citizen empowerment in Spain. In Brickell, Katherine; Fernández Arrigoitia, Melissa \& Vasudevan, Alexander (eds.). Geographies of forced eviction: dispossession, violence, resistance. London: Palgrave Macmillan, p. I67-I90.

Castells, Manuel. (2012). Networks of outrage and hope: social movements in the internet age. Cambridge: Polity Press.

Clapp, Jennifer. (20I4). Financialization, distance and global food politics. The Journal of Peasant Studies, 4I/5, p. 7978I4. doi:10.1080/03066150.2013.875536.

Dale, Gareth. (2010). Karl Polanyi. The limits of the market. Cambridge: Polity Press.

Davey, Ryan. (2019). Suspensory indebtedness: time, morality and power asymmetry in experiences of consumer debt. Economy and society, 48/4, p. 532-553. doi:10.1080/03 085147.2019 .1652985 .

Davis, Gerald F. \& Kim, Suntae. (20I5). Financialization of the economy. Annual Review of Sociology, 4I/I, p. 203-22I. doi:IO.II46/annurev-SOC-073014-II 2402.

Della Porta, Donatella. (2015). Social movements in times of austerity: bringing capitalism back into protest analysis. Cambridge: Polity Press.

Deville, Joe et al. (20I6). Domesticizing financial economies. Studies of finance in between market devices, everyday calculation and government. Paper presented at the Debt Trails Workshop, Budapest.

Diani, Mario. (1992). The concept of social movement. The Sociological Review, 40/I, p. I-25. doi:Io.I I I I/j.I467-954X.I992. tbo2943.x.

Eaton, Charlie et al. (2016). The financialization of US higher education. Socio-Economic Review, I4/3, p. 507-535. doi:ıo.1093/ser/mwvo3o.

Erturk, Ismail et al. (2007). The democratization of finance? Promises, outcomes and conditions. Review of International Political Economy, I4/4, p. 553-575. doi:I0.2307/2526I 930 
Fligstein, Neil \& Goldstein, Adam. (2015). The emergence of a finance culture in American households, 1989-2007. Socio-Economic Review, I3/3, p. 575-601. doi:10.1093/ser/ mwuo35.

Fligstein, Neil \& Shin, Taekjin. (2007). Shareholder value and the transformation of the U.S. economy, I984-200I. Sociological Forum, 22/4, p. 399-424. doi:IO.I I I I/j.I573-786I .2007.00044.x.

Fridell, Gavin. (2013a). Debt politics and the free trade 'package': the case of the Caribbean. Third World Quarterly, 34(4), p. 613-629. doi:I0.1080/oI436597.2013.786286.

Fridell, Gavin. (2013b). Introduction - Politicising debt and development: activist voices on social justice in the new millennium. Third World Quarterly, 34/8), p. I492-I496. do i:I0.1080/OI436597.2013.841389.

Fridell, Gavin. (2013c). Politicising debt and development: activist voices on social justice in the new millennium. Third World Quarterly, 3/4, p. 726-745. doi:Io.IO80/oI43659 7.2013.786294.

Garritzmann, Julian L. (2016). The political economy of higher education finance: the politics of tuition fees and subsidies in OECD countries, I945-2015. London: Palgrave Macmillan.

Geisst, Charles. (2009). Collateral damaged: the marketing of consumer debt to America. New York: Bloomberg Press. González-López, Felipe. (2020a). Micro-credit and the financialization of low-income households. In: Mader, Philip; Mertens, Daniel \& Van der Zwan, Natascha (eds.). The Routledge international handbook of financialization. London: Routledge, p. 30I-3II.

González-López, Felipe. (2020b). The financialization of social policy and the politicization of student debt in Chile. Journal of Cultural Economy, I/I8. doi:Io.1080/I7530350. 2020.1831574.

González-López, Felipe. (2018). Crédito, deuda y gubernamentalidad financiera en Chile. Revista Mexicana de Sociología, 80, p. 88I-908. Retrieved from http://www.scielo.org. $\mathrm{mx} /$ scielo.php?script=sci_arttext\&pid=SoI $88-2503201800$ 040088 I \& $\mathrm{nrm}=$ iso. 
Graeber, David. (20I I). Debt, the first 5,000 years. New York: Melville House.

Guzmán, Sebastian G. (2015). "Should I trust the bank or the social movement?" Motivated reasoning and debtors' work to accept misinformation. Sociological Forum, 30/4, p. 900-924. doi:IO.IIII/socf.I220I.

Hanlon, Joseph. (2000). How much debt must be cancelled? Journal of International Development, I2/6, p. 877-90I. doi:10.1002/I099-I328(200008) I $2: 6<877::$ AID-JID720> 3.0.CO;2-9.

Jasper, James. (2004). A strategic approach to collective action: looking for agency in social-movement choices. Mobilization: An International Quarterly, 9/I, p. I-I6. doi: I0.178I3/maiq.9.I.mII2677546p6336I.

Jayachandran, Seema \& Kremer, Michael. (2003). Odious debt. Wall Street Journal, 96/I, p. 82-92.

Jefferson, Anna. (2013). Narratives of moral order in Michigan's foreclosure crisis. City \& Society, 25/I, P. 92-II2. doi:IO.IIII/ciso.I 2006.

Jones, Tim. (2013). Debt and power: global injustices and grassroots alternatives. Third World Quarterly, 34/8, p. I497 I498. doi:I0.1080/0I436597.2013.84I390.

Kingsolver, Ann. (2008). “As we forgive our debtors": Mexico's El Barzón Movement, bankruptcy policy in the United States, and the ethnography of neoliberal logic and practice. Rethinking Marxism, 20/I, p.I3-27.doi:I0.1080/0893569070173988I.

Krippner, Greta R. (20II). Capitalizing on crisis: the political origins of the rise of finance. Cambridge: Harvard University Press.

Krippner, Greta R. (2005). The financialization of the American economy. Socio-Economic Review, 3/2, p.I73-208. doi: IO.I093/SER/mwioo8.

Kugler, Jacek. (1987). The politics of foreign debt in Latin America a study of the debtors' cartel. International Interactions, I3/2, p. II5-I44. doi:I0.I080/0305062870843467I. Langley, Paul. (2010). The everyday life of global finance: saving and borrowing in Anglo-America. Oxford: Oxford University Press. 
Langley, Paul. (2008). Financialization and the consumer credit boom. Competition \& Change, I2/2, p. I33-I47. doi:IO.II79/102452908X289794.

Lapavitsas, Costas. (20II). Theorizing financialization. Work, Employment \& Society, 25/4, p. 6II-626. doi:IO.II77 lo9500I70II4I9708.

Larson, Ann. (2014). The case for debt resistance. New Labor Forum, 23/2, p. 50-56. doi:I0.II77/I0957960I4526703. Levien, Michael. (2007). India's double-movement: Polanyi and the National Alliance of People's movements. Berkeley Journal of Sociology, 5I, p. II9-I49. Retrieved from www. jstor.org/stable/4I035623.

Macheda, Francesco. (2012). The role of pension funds in the financialisation of the Icelandic economy. Capital \& Class, 36/3, p. 433-473. doi:Io.II77/03098I68I2460753.

Mader, Philip. (20I5). The political economy of microfinance: financializing poverty. Houndmills: Palgrave Macmillan.

Mader, Philip; Mertens, Daniel \& Van der Zwan, Natascha. (2020). The Routledge international handbook of financialization. London: Routledge.

Manning, Robert. (200I). Credit card nation: the consequences of America's addiction to credit. New York: Basic Books.

Marchini, Geneviève. (2004). Financial liberalisation, the banking crisis and the debtors' movement in Mexico. Portal, I/2.

Martin, Randy. (2008). Financialization of daily life. Financialization at work. Philadelphia: Temple University Press.

Montgomerie, Johnna. (2013). America's debt safety-net. Public Administration, 9I/4, p. 87I-888. doi:IO.IIII/j.I4679299.2012.02094.x.

Montgomerie, Johnna. (2006). Giving credit where it is due: public policy and household indebtedness in Anglo-America. Policy and Society, 25/3, p. IO9-I42.

Montgomerie, Johnna \& Tepe-Belfrage, Daniela. (2019). Spaces of debt resistance and the contemporary politics of financialised capitalism. Geoforum, 98, p. 309-317. doi:https://doi.org/Io.10I6/j.geoforum.2018.05.012. 
Ocampo, José Antonio et al. (20I4). La crisis latinoamericana de la deuda desde la perspectiva histórica. Santiago de Chile: Comisión Económica para América Latina y el Caribe.

Ordóñez, Vicente; Feenstra, Ramón A. \& Torney, Simon. (20I5). Citizens against austerity a comparative reflection on Plataforma de Afectados por la Hipoteca (PAH) and Bündnis Zwangsräumung Verhindern (BZV). Araucaria: Revista Iberoamericana de Filosofía, Política, Humanidades y Relaciones Internacionales, I7/34, p. I33-I54.

Peebles, Gustav. (2010). The anthropology of credit and debt. Annual Review of Anthropology, 39, p. 225-240. doi:10.2307/25735109.

Pellandini-Simányi, Léna; Hammer, Ferenc \& Vargha, Zsuzsanna. (2015). The financialization of everyday life or the domestication of finance? Cultural Studies, 29/5-6, p. 733-759. doi:I0.1080/09502386.2015.1017142.

Pettifor, Ann \& Greenhill, Romilli. (2003). Debt relief and the millenium development goals. Retrieved from Human Development Report Office. Occasional Paper. Background paper for HDR.

Polanyi, Karl. (I945). La gran transformación. Ciudad de México: Fondo de Cultura Económica.

Polleta, Francesca \& Jasper, James M. (200I). Collective identity and social movements. Annual Review of Sociology, 27, p. 283-305.

Quinn, Sarah Lehman. (2010). Government policy, housing, and the origins of securitization, I780-1968. Doctoral thesis. Sociology Department/University of California.

Ramsay, Iain. (2012). Between neo-liberalism and the social market: approaches to debt adjustment and consumer insolvency in the EU. Journal of Consumer Policy, 35/4, p. 42I-44I. doi:I0.1007/s10603-0I2-9210-0.

Reyes Tagle, Yovana \& Sehm Patomäk, Katarina. (2007). The rise and development of the global debt movement. A North-South dialogue. Retrieved from Civil Society and Social Movements Programme Paper, 28.

Robinson, J. Gregg. (2013). The white working-class and the foreclosure crisis: tracing the roots of a failed move- 
ment in southern California. Sociological Perspectives, 56/I, p. I3I-I59. Retrieved from www.jstor.org/stable/IO.I525/ sop.20I2.56.I.I3I.

Rona-Tas, Akos \& Guseva, Alya. (2018). Consumer credit in comparative perspective. Annual Review of Sociology, 44/I, p. 55-75. doi:Io.II46/annurev-soc-06oir6-053653.

Ross, Andrew. (2014). You are not a loan: a debtors movement. Culture Unbound, 6, p. I79-188.

Sack, Alexander. (1927). Les effets des transformations des États sur leurs dettes publiques et autres obligations financières. Paris: [s.n.].

Silver, Beverly J. \& Arrighi, Giovanni. (2003). Polanyi's "Double movement": the belle époques of British and U.S. hegemony compared. Politics \& Society, 3I/2, p. 325-355. doi:IO.II77/0032329203252274.

Soederberg, Susanne. (2013). The politics of debt and development in the new millennium: an introduction. Third World Quarterly, 34/4, p. 535-546. doi:Io.Io80/oI436597.20 I3.78628I.

Somers, Jean. (2017). Transnational debt movements: challenging States and international decision-makers, or Intermeshed with these? Voluntas: International Journal of Voluntary and Nonprofit Organizations, 28/3, p. I054-I077. doi:I0.1007/SII266-0I5-9619-6.

Streeck, Wolfgang. (20I4). Buying time: the delayed crisis of democratic capitalism. London: Verso.

Tomz, Michael \& Wright, Mark L. J. (2013). Empirical research on sovereign debt and default. Annual Review of Economics, 5/I, p. 247-272. doi:Io.ir46/annurev-economics-06II09-080443.

Toussaint, Éric. (2019). The debt system. A history of sovereign debts and their repudiation. Chicago: Highmarket Books.

Trumbull, Gunnar. (2014). Consumer lending in France and America: credit and welfare. Cambridge: Cambridge University Press.

Van der Zwan, Natascha. (2014). Making sense of financialization. Socio-Economic Review, I2/I, p. 99-I29. doi:Io.I093/ser/mwto2o. 
Williams, Heather. (200I). Of free trade and debt bondage: fighting banks and the State in Mexico. Latin American Perspectives, 28/4, p. 30-5I. doi:I0.II77/0094582x0102800403. Williams, Heather. (1996). Planting trouble: The Barzón Debtors' Movement in Mexico. San Diego: University of California.

Worth, Owen. (2013). Polanyi's magnum opus? Assessing the application of the counter-movement in international political economy. The International History Review, 35/4, p. 905-920. doi:10.1080/07075332.2013.817464.

Ziderman, Adrian. (2013). Student loan schemes in practice: a global perspective. In: Heller, Donald E. (ed.). Student financing of higher education. A comparative perspective. Abingdon: Routledge, p. 32-6o. 


\section{A SOCIEDADE CONTRA OS MERCADOS A MERCANTILIZAÇÃO DO DINHEIRO E O REPUDIA DA DÍVIDA \\ Resumo}

Dos movimentos sociais de endividados no México, Espanha, Polônia, Croácia e Chile aos movimentos Ocuppy nos Estados Unidos, Israel e Canadá, as organizações que repudiam tanto a dívida quanto a centralidade dos mercados financeiros proliferam em todo o mundo. Neste artigo, me apoio na obra de Polanyi para enquadrar a financeirização da sociedade e as diferentes formas de repúdio ao endividamento como um duplo movimento, caracterizado como uma segunda onda de mercantilização do dinheiro e das tentativas da sociedade de se proteger do avanço das finanças. Baseando-me na literatura secundária e em minha própria investigação etnográfica sobre movimentos sociais de endividados, exploro as semelhanças e diferenças entre as diversas formas de repúdio à dívida por meio de ação coletiva, tanto em nível nacional quanto internacional.

\section{SOCIETY AGAINST MARKETS. THE COMMODIFICATION OF MONEY AND THE REPUDIATION OF DEBT}

Abstract

From anti-debt movements in Mexico, Spain, Poland, Croatia, and Chile to the Occupy movements in the United States, Israel and Canada, organizations repudiating both debt and the centrality of financial markets have proliferated worldwide. In this article, I draw on Polanyi's work in order to frame the financialization of society and different forms of debt repudiation as a double movement, characterized as a second wave of the commodification of money and the attempts by society to protect itself from the advancement of finance. Relying on a secondary literature and my own ethnographic research on debtors' movements, I explore the commonalities and differences between diverse forms of repudiating debt through collective action at both national and international level.

\section{Palavras-chave}

Financeirização; Karl Polanyi; duplo movimento; repúdio à dívida; movimentos sociais de endividados.

\section{Keywords}

Financialization; Karl Polanyi; double movement; debt repudiation; anti-debt movements. 